\title{
Biogas Quantity and Quality from Digestion and Co-Digestion of Food waste and Cow Dung
}

\author{
OJO, OM \\ Department of Civil Engineering, Federal University of Technology, Akure, P.M.B 704, Ondo State, Nigeria \\ Email: omojo@futa.edu.ng
}

\begin{abstract}
The aim of this study is to assess the quantity and quality of biogas produced from single substrate digestion of food waste and cow dung as well as co-digestion of food waste and cow dung. Laboratory sized 25 litre plastic biodigesters were used in this study and the digestion processes was carried out for a 30 day retention period. The results revealed that the cumulative biogas production for the single substrate digestion of cow dung was $7,975 \mathrm{ml}$, the cumulative biogas produced for the single substrate digestion of food waste was $7,742.5 \mathrm{ml}$ while the cumulative volume of biogas produced for the co-digestion of cow dung and food waste was $16,482.5 \mathrm{ml}$. The results also showed that the total volume of methane produced for the single substrate digestion of cow dung was $955 \mathrm{ml}$ while the total methane produced for the single substrate digestion of the food waste was 765 . The total production of methane for the co-digestion of cow dung and food waste was found to be $2,655 \mathrm{ml}$. This study revealed that though the co-digestion process improved biogas quantity and quality, the percentage methane present in the biogas very low. There would be a need to stimulate the digestion and co-digestion process in order to improve the quality of biogas produced.
\end{abstract}

\section{DOI: https://dx.doi.org/10.4314/jasem.v25i7.26}

Copyright: Copyright (C 2021 Ojo. This is an open access article distributed under the Creative Commons Attribution License (CCL), which permits unrestricted use, distribution, and reproduction in any medium, provided the original work is properly cited.

Dates: Received: 10 May 2021; Revised: 28 June 2021; Accepted: 01 July 2021

Keywords: Biogas, methane, single, substrate, co-digestion, food waste, cow dung

Biogas is flammable gas which is obtained through the action of methanogenic bacteria, which work in the absence of oxygen through a process of Anaerobic Digestion (AD) (Tambawal, 2004). Biogas is a renewable energy that can be utilized to meet the ever energy demands of man, without further deterioration of the environment (Roopnarain and Adeleke, 2017). According to Kapdi et al. (2004), ideally, raw biogas contains about 55-65\% methane $\left(\mathrm{CH}_{4}\right)$ and $30-45 \%$ carbon dioxide $\left(\mathrm{CO}_{2}\right)$. AD of waste organic substances (biomass) to biogas is among the few biotechnological processes that can generate bio-fuel and reduce environmental pollution (Zhang et al., 2016). Biogas production by $\mathrm{AD}$ is popular for treating biodegradable wastes because valuable fuel can be produced while destroying the disease - causing pathogens and reducing the volume of disposed waste products (Babatola, 2008). Co- digestion is AD performed on a mixture of at least two different substrates (Alvarez and Lidén, 2008; Cuetos et al., 2011; Ojo, 2017; Ojo et al., 2018; Ojo et al., 2019; Ojo and Babatola, 2020). Co-digestion is a technology that is increasingly being applied for simultaneous treatment of different solid and liquid organic wastes (Bouallagui et al., 2009). Several authors have worked on the digestion and co-digestion of wastes towards biogas production. Gelegenis et al., (2007) optimised the biogas production from olive-oil mill waste-water by co-digesting with diluted poultry-manure. Alvarez and Lidén, (2008) studied the co-digestion of slaughterhouse waste as main substrates with manure, fruit and vegetable waste within a mesophilic semicontinous process. Labatut et al. (2010) and Li et al. (2002) evaluated the use of food wastes as cosubstrates in the production of biogas and discovered that the co-digestion of food waste with other waste was successful in enhancing biogas yields. Li et al. (2009) worked on the anaerobic co-digestion of kitchen waste with cattle manure for biogas production and concluded that the co-digestion process improved biogas yield. Cow dung contains high concentrations of pathogens which need to be effectively managed in order to minimize environmental pollution and public health risks (Thakur, 2006). In the absence of appropriate disposal methods, cow dung can cause diverse environmental and health problems such as odour, greenhouse gas emission and water contamination. Food waste is a major constituent of municipal waste. Restaurants and food processing industries are the major sources of the food waste. Food waste is even generated in considerable amount at the household level. It includes leftover food, dish wash waste, vegetable cut outs, fruit peels and deteriorated fruits and vegetables. The food waste is 
considered to have high organic matter and hence it can be treated anaerobically for biogas production. Uncontrolled decomposition of food waste can lead to greenhouse emission and contamination of ground water as a result of infiltration. Food waste contains highly degradable substances and low nitrogen content, co-digestion with substrates of lower biodegradability and high nitrogen content has been found to immensely boost both biogas yield and digester stability (Owamah and Izinyon, 2015). The aim of this study is to assess the production of biogas and methane from single substrate digestion of food waste and cow dung and co-digestion of food waste and cow dung.

\section{MATERIALS AND METHODS}

Materials for the construction of the bio-digester: The following materials were used for the construction of the bio-digester:

i. 25 litre keg: this was used to hold the substrate material to allow for decomposition and biogas production

ii. $\quad$ PVC pipes of different diameters: These were used at various parts of the digester; at the slurry outlet, slurry inlet and gas holder

iii. Corks: These were used at openings to ensure air tight conditions so as to maintain the anaerobic condition of the bio-digester.

iv. $90^{\circ}$ elbows: These were used to ensure perfect joining of the components.

v. Control valves: these were used at several places to control the inlet of air and to ensure that no air enters into the bio-digester.

vi. $\quad 1 / 4$ inch rubber hose: Used to collect the gas produced from the bio-digester to the measuring cylinder.

Other material used for the experimental set up includes:

i. Conical flask: This was used to hold the calcium hydroxide solution set up to ensure the removal of carbon (IV) oxide.

ii. Measuring cylinder: This is used to hold water used to determine the volume of gas produced.

iii. Tripod stand: This was used to ensure firm holding of the measuring cylinder.

iv. Bowls: This was used to hold water in the water displacement set-up.

Digestion Substrates: The substrates utilized in this study are food waste and animal dung. Several types of food waste were collected from restaurants and event centres within the Federal University of Technology, Akure (FUTA). They were mixed thoroughly until a homogeneous mix was formed. Cow dung and was collected from the Animal Production and Health farm of FUTA
Three digesters were constructed for the purpose of this study. The cow dung and food waste were digested individually and collectively through the process of co-digestion. The content of the digesters is shown in Table 1

Table 1 Contents of the bio-digester

\begin{tabular}{ll}
\hline Digester & Substrate \\
\hline Digester 1 & $100 \%$ Cow Dung Waste \\
Digester 2 & $100 \%$ Food Waste \\
Digester 3 & $50 \%$ Cow Dung + 50\% Food Waste \\
\hline
\end{tabular}

According to Fekadu (2014) and Ojo and Babatola (2020), the quantity of water added was determined using equation 1

$$
\mathrm{Y}=\frac{\mathrm{mTS}-8 \% \mathrm{X}}{8 \%} . \ldots \ldots \ldots(1)
$$

Where, mTS is the mass of total solids, $\mathrm{X}$ is the mass of fresh substrate, $\mathrm{Y}$ is the mass of water added to get $8 \%$ total solids in the digester

Experimental set-up: The volume of biogas and methane content of the biogas were measured using water displacement method. The experimental set-up is shown in Figure 1. The biogas produced from the digester was passed to the first water displacement apparatus. The volume of biogas produced was taken as the volume of water displaced. The biogas was then passed through Calcium Hydroxide $\left(\mathrm{Ca}(\mathrm{OH})_{2}\right)$ solution to remove the Carbon dioxide and other trace gases present in the biogas. The methane content was taken as the volume of water displaced in the second water displacement apparatus.

\section{RESULTS AND DISCUSSIONS}

Biogas yield: Figure 2 shows the graph for the daily biogas yield for the digestion of cow dung, food waste, and co-digestion of cow dung and food waste. From the results, it was observed that the highest volume of biogas produced was $675 \mathrm{ml}$ and this was obtained at Day 22 for the single substrate digestion of cow dung. Also, the highest volume of biogas of $450 \mathrm{ml}$ was produced at Day 24 for the single substrate digestion of the food waste, while the co-digestion of food waste and cow dung recorded its highest volume of $1,425 \mathrm{ml}$ at day 15 .

Cumulative biogas yield: The total biogas yield for the 30 days retention period was determined for the three (3) digestions and presented in figure 3 for the single substrate digestion of cow dung and food waste, and co-digestion of cow dung and food waste. The results revealed that the cumulative biogas production for the single substrate digestion of cow dung was $7975 \mathrm{ml}$ while the cumulative biogas produced for the single substrate digestion of food waste was $7742.5 \mathrm{ml}$. Also, 
the cumulative production of biogas for the codigestion of cow dung and food waste was 16,482.5 $\mathrm{ml}$. The results revealed that the co-digestion of cow dung and food waste produced the highest cumulative volume of biogas.

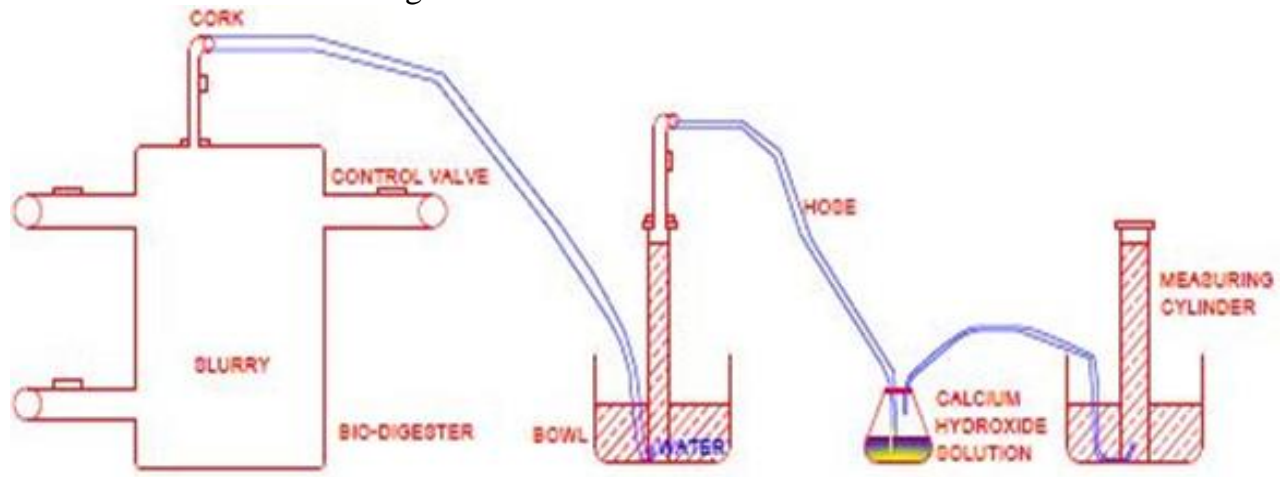

Fig 1: Experimental set-up

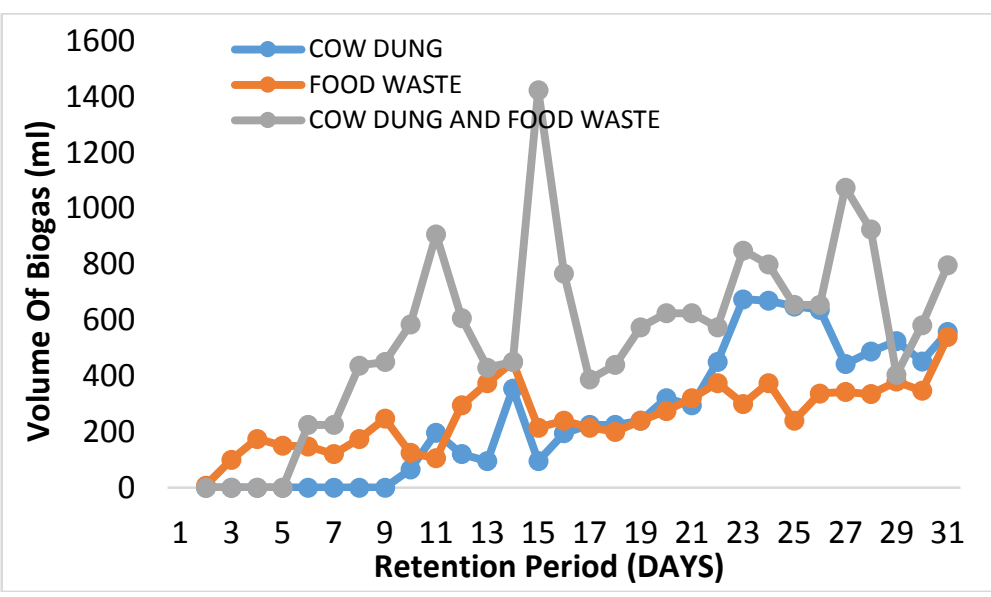

Fig 2: Daily biogas production for the different substrates

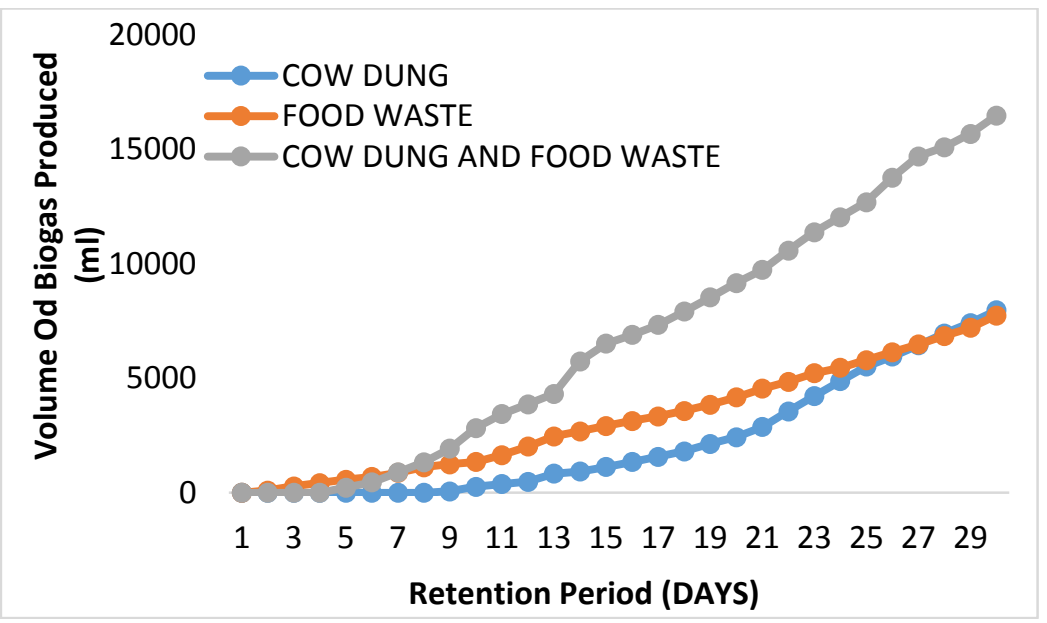

Fig 3: Cumulative volume of biogas for the different substrates

Volume of Methane yield: Figure 4 shows the graph for the daily methane yield for the digestion of cow dung, food waste, and co-digestion of cow dung and food waste. The results revealed that methane was not formed until day 14 and that the highest methane production of $120 \mathrm{ml}$ was at day 24 for the digestion of cow dung, while it was observed that the methane was not formed until day15 and the highest methane produced $(115 \mathrm{ml})$ was at day 24 for the digestion of the food waste. It was also observed that the formation of methane was not until day 9 and the highest 
production of methane of $280 \mathrm{ml}$ was observed at day 24 for the co-digestion of cow dung and food waste.

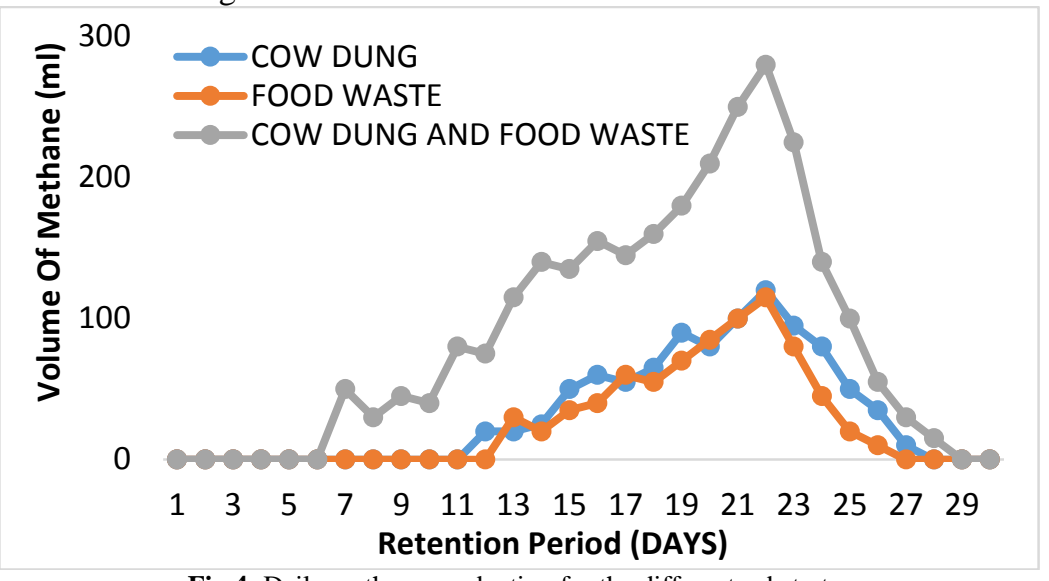

Fig 4: Daily methane production for the different substrates

Cumulative Methane yield: The cumulative methane yield for the 30 days retention period was determined for the three (3) digestions and presented in figure 5. The results revealed that the total methane production for the digestion of cow dung was $955 \mathrm{ml}$ amounting to $11.97 \%$ of the total volume of biogas produced, while the total methane produced for the digestion of the food waste was $765 \mathrm{ml}$, amounting to $9.88 \%$ of the total volume of biogas produced. Also, the total production of methane for the co-digestion of cow dung and food waste was found to be $2,655 \mathrm{ml}$, amounting to $16.11 \%$ of the total volume of biogas produced. These results contradicted the findings of Kapdi et al. (2004). It was observed that the codigestion of cow dung and food waste produced the highest volume of methane. However the percentage of methane present in the biogas produced was very low. This might be due to the fact that the experiments were performed naturally under laboratory conditions and no measures were put in place to influence the quantity and quality of the biogas produced

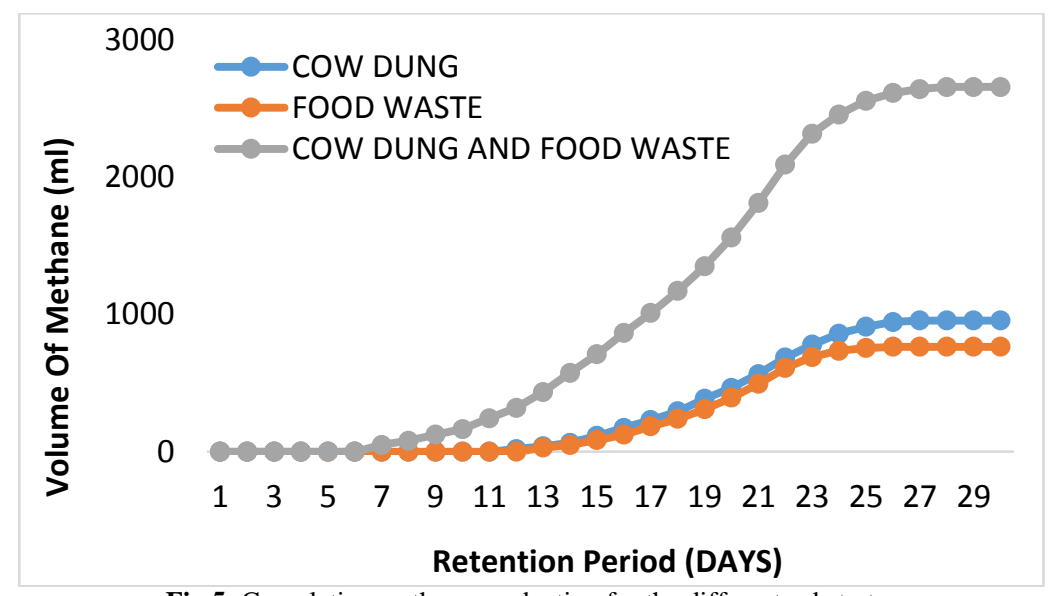

Fig 5: Cumulative methane production for the different substrates

Conclusion: This study asserted that cow dung and food waste which are often viewed as biodegradable municipal wastes can be co-digested to produce biogas. This study further revealed that though the codigestion process improved biogas quantity and quality, the percentage of methane present in the biogas very low. There would be a need to stimulate the digestion and co-digestion process in order to improve the quality of biogas produced and maximize the potential of these wastes to serve as sources of renewable energy.

\section{REFERENCES}

Alvarez, R and Lidén, G (2008). Semi-continuous codigestion of solid slaughterhouse waste, manure, 
and fruit and vegetable waste. Renew. Energ. 33: 726-734.

Babatola, JO (2008). Comparative Study of Biogas Yield Pattern in Some Animal and Household Wastes. Afr. Res. Rev. 2(4):54-68.

Bouallagui, H.; Lahdheb H.; Ben Romdan E.; Rachdi,B. and Hamdi, M (2009). Improvement of fruit and Vegetable waste anaerobic digestion performance and stability with co-substates addition. J. Environ. Manage. 90(5):1844-1849

Cuetos, MJ; Gomez, X; Otero, M; Moran, A (2008). Anaerobic digestion of solid slaughter house waste (SHW) at laboratory scale: influence of codigestion with the organic fraction of municipal solid waste (OFMSW). Biochem. Eng. J. 40, 99106.

Gelegenis, J; Georgakakis, D; Angelidaki, I; Christopoulou; Goumenaki, M (2007). Optimization of biogas production from olive-oil mill wastewater, by codigesting with diluted poultry manure. Appl. Energy 84: 646 - 663

Kapdi, SS; Vijay, VK; Rajesh, SK; Rajendra, P (2004). Biogas Scrubbing, Compression, and Storage: Perspective and Prospectus in Indian Context. Centre for Rural Development and Technology Indian Institute of Technology: New Delhi, India.

Labatut, RA; Angenent, LT; Scott, NR (2014). Conventional mesophilic vs. thermophilic anaerobic digestion: a trade-off between performance and stability? Water Res. 53: 249 258.

Li, Y; Sasaki, H.; Yamashita, K; Seki, K; Kamigochi, I (2002). High-rate methane fermentation of lipidrich food wastes by a high-solids co-digestion process. Water Sci. Technol. 45 (12), 143-150.

Li, R; Chen, L; Li, X; Lar, JS; He, Y; Zhu, B (2009). Anaerobic Codigestion of kitchenwaste with cattle manure for biogas production. Energ. Fuel 23: 2225 - 2228.
Ojo, OM (2017). Biomethanation of Water Hyacinth and Selected Animal Dungs for Biogas Production. Unpublished Ph.D Thesis in the Department of Civil Engineering, The Federal University of Technology, Akure.

Ojo, OM; Babatola, JO; Adesina, AA; Akinola, AO; Lafe, O (2018). Synergistic Effect of co-digesting different mix ratios of Water Hyacinth and Cowdung for Biogas production. FUTAJEET 12 (1): 54 $-59$

Ojo, OM; Babatola, JO; Akinola, AO; Lafe, O; Adelodun, AA (2019). Co-Digestion of Water Hyacinth and Poultry Manure for Improved Biogas yield. ABUAD J. Eng. Res. Dev. 2 (1): 42-48.

Ojo, OM; Babatola, JO (2020). Association between Biogas Quality and Digester Temperature for Selected Animal Dung-Aided Water Hyacinth Digestion Mixes. J. Appli. Sci. Environ. Manage. 24 (6): 966-959.

Owamah, HI; Izinyon, OC (2015). Development of simple-to-apply biogas kinetic models for the Codigestion of Food Waste and Maize Husk. Bioresour. Technol. 194: 83-90.

Tambawal, AD (2004). Chemical assessment of some dungs and prediction of their performance potentials in the generation of Biogas. Nig. J. Renewable Energy 12(1): 12-17.

Thakur, IS (2006). Environmental Biotechnology: Basic Concept and Applications. New Delhi; Ik International Pvt Ltd.

Roopnarain, A; Adeleke, R (2017). Current Status, Hurdles and Future Prospects of Biogas Digestion Technology in Africa. Renew. Sust. Energ. Rev. 67: 1162-1179.

Zhang, Q; Hu, J; Lee, D (2016). Biogas from Anaerobic Digestion Processes: Research Updates. Renew. Energy 98:108-119. 